\title{
The role of neonatal screening in nutritional evolution in the first 12 months after diagnosis of cystic fibrosis
}

\author{
Janine Pruinelli Martins ${ }^{1}$ \\ (iD) Gabriele Carra Forte \\ Miriam Isabel Souza dos Santos Simon ${ }^{3}$ \\ Matias Epifanio ${ }^{4}$ \\ Leonardo Araújo Pinto \\ Paulo José Cauduro Marostica ${ }^{6}$
}

\begin{abstract}
1.Universidade Federal de Ciências da Saúde de Porto Alegre (UFCSPA), Porto Alegre, RS, Brasil 2. Universidade Federal do Rio Grande do Sul (UFRGS), Porto Alegre, RS, Brasil 3. Universidade Federal do Rio Grande do Sul (Cesan/UFRGS), Porto Alegre, RS, Brasil 4. Pontifícia Universidade Católica do Rio Grande do Sul (PUCRS), Porto Alegre, RS, Brasil 5. Pontifícia Universidade Católica do Rio Grande do Sul (PUCRS), Porto Alegre, RS, Brasil 6. Universidade Federal do Rio Grande do Sul (UFRGS), Porto Alegre, RS, Brasil
\end{abstract}

http://dx.doi.org/10.1590/1806-9282.64.11.1032

\section{SUMMARY}

OBJECTIVE: to assess the progression of pediatric cystic fibrosis (CF) patients' nutritional status during the first 12 months after diagnosis and to establish its association with neonatal screening and clinical variables. Patients were recruited from two reference centers in Southern Brazil.

METHODS: Retrospective cohort study was carried out with all the patients diagnosed between 2009 and 2014. Anthropometric, clinic and neonatal screening were collected from medical files. Analysis of anthropometric markers over time was performed by generalized estimating equations. A multivariate regression analysis model to predict the $\triangle$ percentile body mass index (BMI) (BMI percentile difference between one year after the treatment and BMI percentile at diagnosis) was done.

RESULTS: Forty-seven patients were included in the study. Analysis of nutritional data over the period between six months and one year after diagnosis showed significant improvement of BMI, weight/age and weight/height percentiles and Z scores. The neonatal screening was associated with a significant increase of 31.2 points in $\triangle B M I$ percentile at the one-year evaluation $(p<0.05)$. On the other hand, a one-point increase of initial BMI percentile was associated with a reduction of 0.6 points in $\triangle B M I$ percentile.

CONCLUSION: This study demonstrated the role of neonatal screening in the nutritional status of patients diagnosed with CF in the first year after diagnosis. Early diagnosis can significantly contribute to the achievement of appropriate anthropometric indicators and important nutritional recovery of CF patients.

KEYWORDS: Cystic fibrosis. Neonatal screening. Nutritional assessment. Anthropometry.

\section{INTRODUCTION}

Cystic Fibrosis (CF) is accompanied by chronic obstructive pulmonary disease, pancreatic insufficiency with poor digestion and poor absorption of nutrients, leading to the worsening of the nutritional status ${ }^{1}$. The prognosis and the life expectation increased in virtue of progress that offered an intense and proper nutritional follow-up from the diagnosis ${ }^{2}$.
The neonatal screening for $\mathrm{CF}$ with early treatment and identification of the pancreatic disease and proper nutritional management has been associated with the reduction of nutritional deficits and improvement of growth parameters over the years ${ }^{2,3}$. Despite an existing gap of evidence about the advantage of neonatal screening in relation to the progres-

DATE OF SUBMISSION: 15-Mar-2018

DATE OF ACCEPTANCE: 24-Mar-2018

CORRESPONDING AUTHOR: Miriam Isabel Souza dos Santos Simon

Rua Ramiro Barcelos, 2350 CEP 90035-903 - Porto Alegre - RS, Brasil

Phones: (55) 5133598183 / (55) 51998778648

E-mail: misantos@hcpa.edu.br 
sion of the pulmonary disease and survival, the studies show an advantage in the pulmonary function up to at least 8 to 10 years old ${ }^{4}$. Besides that, the strong association of the nutritional status and pulmonary function $^{5,6}$ and the increase of survival ${ }^{7}$ indicate a possible improvement of morbimortality in the patients diagnosed by neonatal screening.

In Brazil, neonatal screening for CF in the Brazilian Unified Health System (SUS - Sistema Único de Saúde) was implemented with the publication in the Official Federal Gazette on 06/06/2001, Ordinance $822^{8}$, that governs the rules for its performance. However, Rio Grande do Sul started the neonatal screening for CF by SUS in 2012 only. Nowadays, the neonatal screening represents an important tool, which is responsible for almost 70\% of diagnosis carried out in 2014, in Brazil. In any case, the median age of patients diagnosed by the symptoms in Brazil is still high (3.82 years), particularly when compared to the patients diagnosed by neonatal screening (0.14 year) ${ }^{9}$.

The nutritional status in the diagnosis is directly associated with age that is carried out and at the beginning of the treatment. On the other hand, the evolution of the nutritional state in the first year after diagnosis has been poorly studied in Brazil. The objective of this study was to assess the evolution of the nutritional status of pediatric patients with CF from two reference centers of Rio Grande do Sul during the first 12 months after diagnosis and to establish an association with neonatal screening and clinical variables.

\section{METHODS}

Retrospective cohort study carried out with all patients with CF diagnosed between 2009 and 2014, assisted in the outpatient clinic of Pediatric Pulmonology of Hospital de Clínicas de Porto Alegre (HCPA) and outpatient CF clinic of Hospital São Lucas (HSL) of Pontifícia Universidade Católica do Rio Grande do Sul. These hospitals are reference centers with a multidisciplinary team in the treatment of patients with CF in Rio Grande do Sul, representing $75 \%$ of the service to these patients.

The diagnosis of CF was confirmed by two doses of electrolytes in sweat by the method of pilocarpine iontophoresis or the presence of two mutations known to be originating agents of the disease.

The collection period was from January to August of 2015. The patients' details with a diagnosis of CF in nutritional and clinical follow-up in the outpatient department of HCPA and HSL were collected from its electronic records. A structured data sheet was used containing date of birth, sex, date of diagnosis, neonatal screening held, genetic identification and pancreatic insufficiency. The genetic identification was carried out by the method of polymerase chain reaction (PCR). The pancreatic insufficiency was established by clinical diagnosis and dose of fecal elastase in cases that were not clinically evident, such as malformed stools and inappropriate weight gain. In the diagnosis, after 6 and 12 months, the following data were collected: presence and type of bacteria colonization, number of usage days of antibiotics in the period, serum albumin (verified only at the diagnosis and after one year), anthropometric measurements and respiratory systems (cough, increased sputum, etc.). The bacteria colonization was proven by sputum culture, when available, or culture of an oropharyngeal swab in other cases. The dose of serum albumin was carried out by the bromocresol green colorimetric method. The collected anthropometric measures were the weight and height; the body mass index (BMI), percentile and Z score of BMI by age (BMI/A), weight by age (W/A), weight by height (W/H) and height by age (H/A) were calculated, according to the curves of World Health Organization $(\mathrm{WHO})^{10}$. The nutritional diagnosis was carried out in accordance with the recommended criteria for $\mathrm{CF}$ that establish cutoff points of BMI/A above 50 percentile ${ }^{5}$. Nutritional risk corresponds to the BMI/A between 10 and 50 percentiles. The poor nutrition is classified when BMI/A is below 10 percentile ${ }^{11,12}$. The $\mathrm{BMI} / \mathrm{A}$ percentile values above 85 were classified as overweight and above 97 percentile as obesity ${ }^{13}$.

The data analysis was carried out with the assistance of the SPSS program, version 18.0. The continuous variables were described by average and standard deviation or median and interquartile range. The categorical variables were described using absolute and relative frequencies. For analysis of anthropometric indicators and other variables in the study, the generalized estimating equations (GEE) were used, with analysis of the significant difference between the times by the Wald chi-square test and Bonferroni test. The evolution of the anthropometric variables was controlled for pancreatic insufficiency, the presence of homozygous F508 del, neonatal screening, bacteria colonization and age of diagnosis.

The multivariate regression framework was used 
to predict the $\Delta \mathrm{BMI} / \mathrm{A}$ percentile (difference between $\mathrm{BMI} / \mathrm{A}$ percentile, one year after the treatment and $\triangle \mathrm{BMI} / \mathrm{A}$ percentile at the time of diagnosis). The level of significance established was $5 \%$.

This project was approved by the Research Ethics Committee of HCPA under the opinion number 967.715, Project number 150.293 and Ethics Committee of Hospital São Lucas under the opinion number 1.294.834.

\section{RESULTS}

All patients $(\mathrm{n}=47)$ diagnosed with $\mathrm{CF}$ between the years 2009 and 2014, in which 30 of HCPA and 17 of HSL, participated in the study. There were no losses by discontinuity of follow-up or death in the period assessed. Sample characterization is presented in Table 1. The age of diagnosis ranged from 2 months to 10 years and 2 months years old, in which the median is equal to 3.2 months. The neonatal screening was carried out in $30(63.8 \%)$ patients, 19 (40.4\%) patients were homozygous for F508del mutation and 45 (95.7\%) showed pancreatic insufficiency.

In relation to the nutritional status, at that time of diagnosis, 28 patients (60\%) were classified with poor nutrition, 12 (25\%) with nutritional risk, six (13\%) eutrophic and one (2\%) with overweight. After one year of follow-up, six patients (13\%) remained with poor nutrition, 15 (32\%) with nutritional risk, 16 (34\%) eutrophic, seven $(15 \%)$ with overweight and three $(6 \%)$ with obesity. Graph 1 shows the evolution of nutritional variables during 12 months of follow-up.

The analysis of nutritional data over a period of six months and one year after the diagnosis showed a significant improvement in the parameters of per-

TABLE 1. CHARACTERIZATION OF THE SAMPLE OF PEDIATRIC PATIENTS WITH CYSTIC FIBROSIS DIAGNOSIS FROM 2009-2014 IN HOSPITAL DE CLÍNICAS DE PORTO ALEGRE AND HOSPITAL SÃO LUCAS

\begin{tabular}{l|l} 
Variables & $\mathrm{n}=47$ \\
\hline $\begin{array}{l}\text { Sex }-\mathrm{n}(\%) \\
\text { Male }\end{array}$ & $24(51.1)$ \\
\hline Age at diagnosis (years) - Median (p25-75) & $0.27(0.15-1.33)$ \\
\hline Neonatal screening - (\%) & $30(63.8)$ \\
Genetics - n (\%) & $38(80.9)$ \\
\hline $\begin{array}{l}\triangle F 508 \text { Heterozygote } \\
\triangle \text { F508 Homozygote }\end{array}$ & $13(27.7)$ \\
Others & $19(40.42)$ \\
Unidentified Mutation & $1(2.1)$ \\
Pancreatic insufficiency $-\mathrm{n}(\%)$ & $5(10.6)$ \\
\hline
\end{tabular}

$\mathrm{N}=$ number of sample; $\mathrm{F}=$ Phenylalanine centile and $\mathrm{Z}$ score of BMI, W/A, and W/H in each period analyzed. In relation to the H/A index, the increase of percentile and $\mathrm{Z}$ score was significant after six months and one year when compared to the diagnosis, but between the periods of six months and one year, there was no significant difference statistically. The albumin showed a significant improvement after one year of follow-up when compared to the diagnosis (Table 2).

In relation to the bacteria colonization, it was noted in the diagnosis that $17 \%$ of patients already presented Pseudomonas aeruginosa, and one year later, this number increased to $30 \%$; however, this difference was not significant between the times assessed. It was noted a significant difference between diagnosis colonization and after 12 months $(\mathrm{p}=0.02)$, with an increase of bacteria colonization over time, but no significant difference between bacteria analyzed (Staphylococcus aureus, Methicillin-resistant Staphylococcus aureus, Pseudomonas aeruginosa mucoide, Burkholderia cepacia, and other bacteria). The use of antimicrobial treatment did not present significant difference between the periods analyzed, although it has increased the medium number of usage days of medications. There was also no statistically significant difference in respiratory symptoms during periods.

The improvement of the nutritional status in patients with CF noted over time by BMI/A percentile was statistically different at the diagnosis at six months and after one year of follow-up, even when controlled to pancreatic insufficiency, presence of homozygous F508 del, neonatal screening, bacterial colonization and age of diagnosis.

After analyzing individual variables over the time, a model was built to predict the BMI/A percentile $\Delta$,

TABLE 2. ANALYSIS OF THE MEAN OF THE NUTRITIONAL PARAMETERS IN THE THREE DIFFERENT MOMENTS OF THE STUDY: AT THE DIAGNOSIS, AFTER 6 MONTHS, AND AFTER 12 MONTHS

\begin{tabular}{l|l|l|l|l} 
Variable & $\begin{array}{l}\text { Diagnosis } \\
(n=47)\end{array}$ & $\begin{array}{l}6 \text { months } \\
(n=47)\end{array}$ & $\begin{array}{l}12 \text { months } \\
(n=47)\end{array}$ & P value \\
\hline Albumin & $3.50 \pm 0.15^{a}$ & - & $4.34 \pm 0.04^{c}$ & $<0.001$ \\
\hline BMI (percentile) & $21.64 \pm 3,77^{a}$ & $42.63 \pm 4.46^{b}$ & $55.11 \pm 4.18^{c}$ & $<0.001$ \\
\hline W/A (percentile) & $15.49 \pm 3,45^{a}$ & $33.91 \pm 4.45^{b}$ & $44.30 \pm 4.34^{c}$ & $<0.001$ \\
\hline W/H (percentile) & $26.68 \pm 4,21^{a}$ & $40.57 \pm 4.93^{b}$ & $53.57 \pm 4.46^{c}$ & $<0.001$ \\
\hline $\mathrm{H} / \mathrm{A}$ (percentile) & $18.02 \pm 3,79^{\mathrm{a}}$ & $27.99 \pm 3.88^{\mathrm{b}}$ & $31.85 \pm 4.14^{\mathrm{b}}$ & 0.005 \\
\hline $\begin{array}{l}\mathrm{n}=\text { number of sample; BMI = Body Mass Index; } \mathrm{W} / \mathrm{A}=\text { weight for age; } \mathrm{W} / \mathrm{H}=\text { weight } \\
\text { for height; H/A= height for age. Different letters represent significant differences } \\
(\mathrm{p}<0.05) \text { between the situations }\end{array}$
\end{tabular}


described in Table 3. The screening and BMI/A percentile of diagnosis were significant to define this percentile difference before and after the treatment. The neonatal screening was associated with a significant increase of 31.2 points in the BMI/A percentile $\Delta$ during one year. On the other hand, one point more of initial BMI/A percentile was associated with a reduction of 0.6 point in BMI/A percentile $\Delta$ during the period analyzed.

\section{DISCUSSION}

It was noted significant improvement in the nutritional status of patients with CF after one year of follow-up, showing the importance of the nutritional treatment to these patients. In addition, the neonatal screening was associated with a higher substantially increase of BMI/A percentile, highlighting the importance of early treatment and diagnosis.

The follow-up and early nutritional intervention offered the evolution of the nutritional status, with a decrease of approximately four times in the number of patients with poor nutrition and increase of three times in the number of patients with the good nutritional state when compared to the period in relation to this diagnosis. The nutritional evolution was evidenced by the significant difference between
TABLE 3. MULTIPLE LINEAR REGRESSION INCLUDING NEONATAL SCREENING AND PERCENTILE OF BMI AT THE DIAGNOSIS AND OUTCOME $\triangle$ BMI PERCENTILE

\begin{tabular}{l|l|l|l}
\multicolumn{1}{l}{ Variables } & $\beta$ & \multicolumn{1}{l}{$\mathrm{Cl} 95 \%$} & P value \\
\hline Neonatal screening & 31.2 & $(5.73 / 49.07)$ & $<0.05$ \\
\hline BMI percentile at the diagnosis & -0.60 & $(-0.94 /-0.27)$ & $<0.01$ \\
\hline \multicolumn{4}{|l}{ Percentile of BMI = Delta percentile of BMI; BMI = Body Mass Index; $\mathrm{Cl}=$ Confi- }
\end{tabular}
dence interval.

the variation of three times analyzed in relation to the anthropometric parameters of W/A and BMI/A. H/A percentile showed a significant difference at the diagnosis with after one year of follow-up, showing a higher increase in the first six months and a stabilization of the period between six months to one year. Ranganathan et al. ${ }^{14}$, analyzing 42 patients with CF at the diagnosis and after three years of follow-up, found similar results.

The average BMI/I and P/E percentiles after one year of diagnosis achieved the average for age and target established for $\mathrm{CF}$, reinforcing the envisioned provisions in the literature, whose assessment of the nutritional status and dietary advice must be instant as soon as the diagnosis was established, with the purpose of reaching the target established and slow the progression of the disease ${ }^{15,16}$. On the other hand, the H/A indicators, despite remaining below the av-

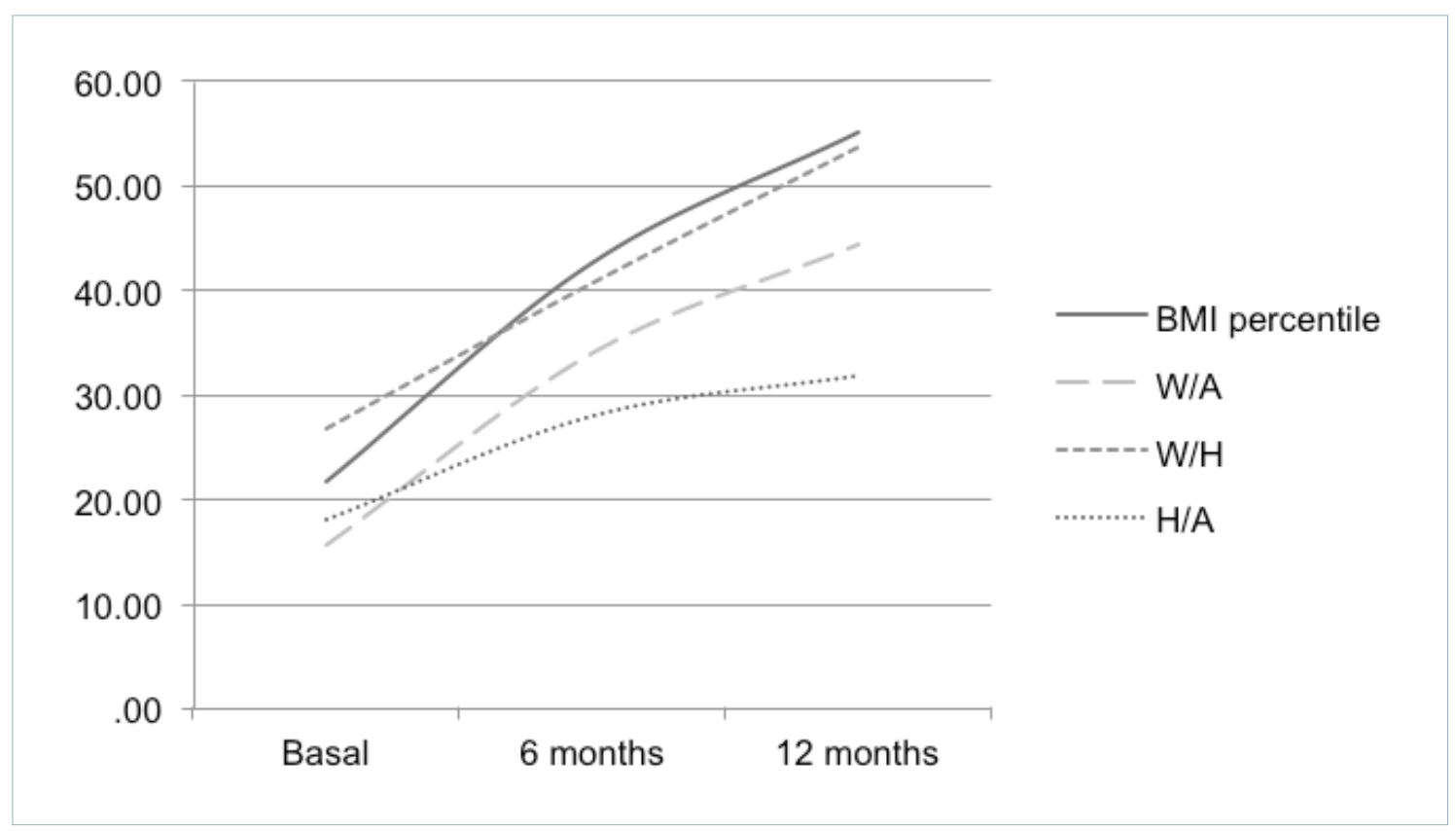

$\mathrm{BMIP}=$ Body Mass Index percentile. WAP= Weight for age percentile. WHP= Weight for height percentile. $\mathrm{HAP}=$ Height for age percentile 
erage of age, showed an increase of approximately 14 points. The height is one of the best indicators of the child's health status, once it is currently influenced by environmental, emotional and socio-economic factors, and ethnic factors ${ }^{17}$. In $\mathrm{CF}$, the height is an important nutritional indicator in view of its association to the survival of these patients ${ }^{18}$.

The neonatal screening was the main gaining predictor of $\mathrm{BMI} / \mathrm{I}$ percentile in the period of one year after the diagnosis. Nowadays, only 15 Brazilian states are qualified to perform the screening for $\mathrm{CF}$ in Brazil and, among the difficulties mentioned, there are high cost for screening, false positives, and false negatives, as well as the lack of qualified teams to assist these patients. Despite little evidence in relation to the difference in the evolution of the disease, among patients diagnosed by neonatal screening and those who had their diagnosis after the beginning of symptoms, in relation to the nutritional status, studies have proven that patients diagnosed by neonatal screening have better nutritional parameters, especially during the first childhood ${ }^{2,19,20}$. Wisconsin Cystic Fibrosis Neonatal Screening Projetc ${ }^{3}$ also evidenced that patients diagnosed by neonatal screening persevered with better parameters of weight and height in a segment for 16 years. Zhang et al. ${ }^{21}$ showed that in adult life, the screening patients reached a height higher than those diagnosed by symptoms.

Another marker used in this study was the analysis of albumin, which is also a marker of nutritional status, in the CF, is also studied by its property as a pulmonary antioxidant, preventing pulmonary damage $^{22}$. This study showed a significant increase in the plasmatic levels of albumin between the diagnosis and after 12 months, from the limit to the diagnosis of poor nutrition and reaching mean values of 4.34 $\mathrm{mg} / \mathrm{dL}$. Simon et al..$^{23}$ reported an association of albumin above $4.1 \mathrm{mg} / \mathrm{dL}$ with better pulmonary function.

In relation to the pulmonary infection, despite not being noted the significant difference between bacteria analyzed in the beginning and the finishing of the study, it is highlighted the high prevalence of colonization by Pseudomonas aeruginosa in the diagnosis and its increase after one year, achieving 30\% of the sample. This infection is a determining factor for worsening of pulmonary disease in patients with $\mathrm{CF}$, consequently, with reduction of survival ${ }^{24,25}$. Lim et al. ${ }^{26}$, monitoring 104 patients after neonatal screening in London, noted that $47 \%$ of them already showed Pseudomonas aeruginosa at 2 years old.

The limitation of the study is related to the sample size and the fact of being a retrospective study, in which there is no control of standard assessments carried out. Another limitation was the lack of social and economic data, as well as the treatment compliance, which did not appear on the patients' records. However, the relevance of this study is due to the fact that data of two reference centers in Southern Brazil support the findings of international literature and reinforce the importance of early diagnosis and the institution of treatment for a better prognostic also in our country.

\section{CONCLUSION}

This study proves the important role of neonatal screening in the nutritional evolution of patients diagnosed with $\mathrm{CF}$ in Brazil in the first year after diagnosis. Therefore, the early diagnosis, combined with treatment of multiprofissional teams in Reference Centers, may significantly contribute to the nutritional recovery of patients with CF.

\section{Acknowledgments}

To the Department of Pediatric Pulmonology of Hospital de Clínicas de Porto Alegre (HCPA), the Hospital São Lucas of Pontifícia Universidade Católica do Rio Grande do Sul (PUCRS) and Nutrition Program of Universidade Federal de Ciências da Saúde de Porto Alegre, represented by Fabiana Viegas Raimundo.

\section{RESUMO}

OBJETIVO: Avaliar a evolução do estado nutricional de pacientes pediátricos com fibrose cística (FC), provenientes de dois centros de referência do sul do Brasil, durante os 12 primeiros meses após o diagnóstico e estabelecer associação com a triagem neonatal e com variáveis clínicas.

MÉTODOS: Estudo de coorte retrospectivo realizado com todos os pacientes diagnosticados entre 2009 e 2014. Foram coletados dados antropométricos, clínicos e de realização da triagem neonatal a partir dos prontuários dos pacientes. A análise dos indicadores antropométricos ao longo do tempo foi realizada por equações de estimativas generalizadas. Utilizou-se o modelo de análise de regressão multivariada para predizer o D percentil índice de massa corporal - IMC/I (diferença entre percentil de IMC/I um ano após o tratamento e percentil de IMC/I no momento do diagnóstico).

RESULTADOS: Participaram do estudo 47 pacientes. A análise dos dados antropométricos ao longo do período de seis meses e um ano 
após o diagnóstico demonstrou melhora significativa dos parâmetros de percentil e escore Z de IMC/I, peso/idade e peso/estatura em cada período analisado. A realização da triagem neonatal foi associada com um aumento significativo de 37,2 pontos no $\Delta$ percentil de IMC/I durante o período de um ano $(p<0,05)$. Por outro lado, um ponto a mais de percentil de IMC/I inicial foi associado com uma redução de 0,6 ponto no $\Delta$ percentil de IMC/I $(p<0,01)$.

CONCLUSÃO: O presente estudo evidencia o papel da triagem neonatal na evolução antropométrica de pacientes com FC no primeiro ano após o diagnóstico. O diagnóstico precoce pode contribuir significativamente para a recuperação nutricional desses pacientes.

PALAVRAS-CHAVE: Fibrose cística. Triagem neonatal. Avaliação nutricional. Antropometria.

\section{REFERENCES}

1. Rosa FR, Dias FG, Nobre LN, Morais HA. Fibrose cística: uma abordagem clínica e nutricional. Rev Nutr. 2008;21(6):725-37.

2. Salvatore D, Buzzetti R, Baldo E, Forneris MP, Lucidi V, Manunza D, et al. An overview of international literature from cystic fibrosis registries. 2. Neonatal screening and nutrition/growth. J Cyst Fibros. 2010;9(2):75-83.

3. Farrell PM, Lai HJ, Li Z, Kosorok MR, Laxova A, Green CG, et al. Evidence on improved outcomes with early diagnosis of cystic fibrosis through neonatal screening: enough is enough! | Pediatr. 2005;147(3 Suppl):S36.

4. Wang SS, O'Leary LA, Fitzsimmons SC, Khoury MJ. The impact of early cystic fibrosis diagnosis on pulmonary function in children. I Pediatr. 2002;141(6):804-10

5. Stallings VA, Stark LJ, Robinson KA, Feranchak AP, Quinton H; Clinical Practice Guidelines on Growth and Nutrition Subcommittee; Ad Hoc Working Group. Evidence-based practice recommendations for nutrition-related management of children and adults with cystic fibrosis and pancreatic insufficiency: results of a systematic review. J Am Diet Assoc. 2008;108(5):832-9.

6. Lai HI, Shoff SM, Farrell PM; Wisconsin Cystic Fibrosis Neonatal Screening Group. Recovery of birth weight z score within 2 years of diagnosis is positively associated with pulmonary status at 6 years of age in children with cystic fibrosis. Pediatrics. 2009;123(2):714-22.

7. Buzzetti $R$, Salvatore $D$, Baldo E, Forneris MP, Lucidi V, Manunza D, et al. An overview of international literature from cystic fibrosis registries: 1. Mortality and survival studies in cystic fibrosis. J Cyst Fibros. 2009;8(4):229-37.

8. Brasil. Ministério da Saúde. Portaria GM/MS no 822 de 06 de junho de 2001. Brasília: Ministério da Saúde; 2001.

9. Grupo Brasileiro de Estudos em Fibrose Cística. Registro Brasileiro de Fibrose Cística:; 2014. [cited Feb 12, 2018]. Available from: http://portalgbefc.org.br/wp-content/uploads/2016/11/Registro2014_v09.pdf

10. Onis M, Onyango AW, Borghi E, Siyam A, Nishida C, Siekmann J. Development of a WHO growth reference for school-aged children and adolescents. Bull World Health Organ. 2007;85(9):660-7.

11. Borowitz D, Baker RD, Stallings V. Consensus report on nutrition for pediatric patients with cystic fibrosis. I Pediatr Gastroenterol Nutr. 2002;35(3):246-59.

12. Turck D, Braegger CP, Colombo C, Declerca D, Morton A, Pancheva R, et al. ESPEN-ESPGHAN-ECFS guidelines on nutrition care for infants, children, and adults with cystic fibrosis. Clin Nutr. 2016;35(3):557-77.

13. Brasil. Ministério da Saúde. Secretaria de Atenção à Saúde. Departamento de Atenção Básica. Protocolos do Sistema de Vigilância Alimentar e Nu- tricional - SISVAN na assistência à saúde. Brasília: Ministério da Saúde; 2008.

14. Ranganathan SC, Parsons F, Gangell C, Brennan S, Stick SM, Sly PD; Australian Respiratory Early Surveillance Team for Cystic Fibrosis. Evolution of pulmonary inflammation and nutritional status in infants and young children with cystic fibrosis. Thorax. 2011;66(5):408-13.

15. Scaparrotta A, Di Pillo S, Attanasi M, Consilvio NP, Cingolani A, Rapino $D$, et al. Growth failure in children with cystic fibrosis. J Pediatr Endocrinol Metab. 2012;25(5-6):393-405.

16. Chaves CRMM, Cunha ALP. Avaliação e recomendações nutricionais para crianças e adolescentes com fibrose cística. Rev Paul Pediatr. 2012;30:131-8.

17. Diago Cabezudo Jl, Carrascosa Lezcano A, del Valle Núñez C), Ferrández Longás A, Gracia Bouthelier R, Pombo Arias M. Idiopathic short stature: definition and treatment. An Pediatr (Barc). 2006;64(4):360-4.

18. Beker LT, Russek-Cohen E, Fink RJ. Stature as a prognostic factor in cystic fibrosis survival. J Am Diet Assoc. 2001;101(4):438-42.

19. Dijk FN, Fitzgerald DA. The impact of newborn screening and earlier intervention on the clinical course of cystic fibrosis. Paediatr Respir Rev. 2012;13(4):220-5.

20. Dankert-Roelse JE, Mérelle ME. Review of outcomes of neonatal screening for cystic fibrosis versus non-screening in Europe. J Pediatr. 2005;147(3 Suppl):S15-20.

21. Zhang Z, Lindstrom M|, Farrell PM, Lai HJ; Wisconsin Cystic Fibrosis Neonatal Screening Group. Pubertal height growth and adult height in cystic fibrosis after newborn screening. Pediatrics. 2016;137(5).

22. Winklhofer-Roob BM. Cystic fibrosis: nutritional status and micronutrients. Curr Opin Clin Nutr Metab Care. 2000;3(4):293-7.

23. Simon MISS, Drehmer M, Abreu e Silva FA, Hoffmann A, Druck Ricachinewsky C, Fonseca Andrade Procianoy E, et al. Association of nutritional status, plasma, albumin levels and pulmonary function in cystic fibrosis. Nutr Hosp. 2011;26(6):1322-7.

24. Sanders DB, Li Z, Laxova A, Rock MJ, Levy H, Collins J, et al. Risk factors for the progression of cystic fibrosis lung disease throughout childhood. Ann Am Thorac Soc. 2014;11(1):63-72.

25. Stern M, Wiedemann B, Wenzlaff P; German Cystic Fibrosis Quality Assessment Group. From registry to quality management: the German Cystic Fibrosis Quality Assessment project 1995 2006. Eur Respir ). 2008;31(1):29-35.

26. Lim MT, Wallis C, Price JF, Carr SB, Chavasse RJ, Shankar A, et al. Diagnosis of cystic fibrosis in London and South East England before and after the introduction of newborn screening. Arch Dis Child. 2014;99(3):197-202. 